Cordova Jurnal

ISSN (P) 2302-3155,

(e) 2714-5808

Vol. 9, No. 12019

\title{
BACA-BACA SANRO ANA': TRADISI DAN RELIGI PADA KELAHIRAN TRADISIONAL MASYARAKAT BUGIS DI SULAWESI SELATAN
}

\author{
Firman Saleh, S.S., S.Pd., M. Hum.
}

fiermansaleh@yahoo.com

\author{
Universitas Hasanuddin, Makassar Indonesia
}

\begin{abstract}
Abstrak
Baca-baca Sanro Ana' merupakan ketidakjelasan bentuk dan kekaburan makna yang diyakini masyarakat Bugis di Sulawesi Selatan dalam kelahiran tradisional menggelitik dan mendorong untuk mengungkapkannya. Penelitian ini bertujuan untuk menjelaskan tradisi dan religi yang menjadi kepercayaan dibungkus dalam baca-baca sanro ana' yang berupa mantra atau sastra yang sangat tradisional. Bentuknya yang berupa puisi lama yang terdiri dari pembuka, isi dan penutup. Metode yang digunakan dalam penelitian ini adalah metode analisis deskriptif kualitatif dengan berorientasi pada tuturan berupa mantra atau baca-baca sanro ana' itu sendiri. Data didapatkan dengan melakukan observasi, wawancara, merekam, mencatat. Hasil penelitian menjelaskan bentuk mantra sanro ana' adalah puisi lama atau puisi tradisional yang terdiri dari beberapa baris, namun tidak memiliki rima yang beraturan. Bentuk mantra yang berupa puisi lama yang terdiri dari pembuka, isi dan penutup. Mantra tidak dapat dimaknai secara langsung dari setiap kata yang terdapat dalam mantra sanro ana', sebab kata-katanya bermakna metafora atau ungkapan perumpamaan. Mantra yang diungkapkan oleh sanro ana' pada tradisi tujuh bulanan merupakan bahasa yang bermakna kekuatan, proses kelahiran dalam tahap kesakitan bermakna kemudahan, serta saat keluarnya bayi dari kandungan ibu sanro ana' meniupkan atau membacakan mantranya yang mengandung yang bermakna keselamatan. Mantra terdiri atas beberapa jenis berdasarkan fungsi dan kegunaannya karena berhubungan denga alam gaib, dan menggunakan pilihan kata pengungkapan yang tepat. Mantra berfungsi sebagai alat utama bagi Sanro Ana', pengintegrasian diri dengan Tuhan penciptanya alam semesta, permintaan izin kepada unsur yang terdapat dalam diri manusia, penolak bala' dan doa pengharapan.
\end{abstract}


Cordova Jurnal

ISSN (P) 2302-3155,

(e) 2714-5808

Vol. 9, No. 12019
Jurnal kajian Bahasa dan Budaya terbit 2 kali setahun oleh UPT. Pusat Pengembangan

Bahasa (P2B) UIN Mataram. Tersedia online pada

https://journal.uinmataram.ac.id/index.php/cordova

Kata Kunci: Baca-Baca, Sanro Ana', Tradisi, Religi dan Kelahiran Tradisional Bugis

\section{PENDAHULUAN}

Masyarakat Bugis menyimpan historis kehidupan masyarakatnya yang tetap terwujud dari zaman ke zaman. Pola tingkah lakunya terbentuk secara kumulatif pada zamannya yang lampau. Generasigenerasi yang ada di belakangnya memperoleh dan mewarisi hal itu sebagai warisan sosial yang dipandangnya sebagai ide-ide tradisional yang sangat berharga dari leluhurnya. Ide-ide tradisional itu mengandung sejumlah nilai yang memengaruhinya ketika membuat keputusan dalam menghadapi situasi tertentu. Ia dapat mengetahui hal tersebut karena nilai itu dapat mengontrol untuk mendengar dan melihat orang tuanya. Berapa banyak yang dilihat dan didengar bergantung pada nilai-nilai yang dihidupkan dan dipelihara sebagai pedoman hidup sehari-hari.

Tuturan yang berbentuk mantra sebagai bentuk puisi tentunya mempunyai ciri sebagaimana halnya dengan karya klasik lainnya, antara lain tidak memiliki nama pengarang atau biasa disebut anonim. Itulah sebabnya mantra dikatakan sebagai salah satu jenis sastra puisi yang tertua. Penyebaran sastra lama termasuk mantra berlangsung secara lisan dengan menggunakan sistem yang ketat.

Umumnya baca-baca diberikan kepada generasi pelanjut keluarga yang dianggap layak mengetahuinya, baca-baca diberikan dukun atau orang-orang yang dituakan dalam masyarakat Bugis. Mantra termasuk dalam genre sastra lisan yang populer di masyarakat, sebagaimana pantun dan syair. Hanya saja penggunaannya lebih eksklusif, karena hanya dituturkan oleh orang tertentu saja, seperti pawang dan dukun. Menurut masyarakat Bugis Bugis pada umumnya, pembacaan mantra diyakini dapat menimbulkan kekuatan gaib untuk membantu meraih tujuan-tujuan tertentu. Mantra sebenarnya lebih sesuai digolongkan ke 
Cordova Jurnal

ISSN (P) 2302-3155,

(e) 2714-5808

Vol. 9, No. 12019
Jurnal kajian Bahasa dan Budaya terbit 2 kali setahun oleh UPT. Pusat Pengembangan

Bahasa (P2B) UIN Mataram. Tersedia online pada

https://journal.uinmataram.ac.id/index.php/cordova

dalam bentuk puisi bebas, yang tidak terlalu terikat pada aspek baris, rima dan jumlah kata dalam setiap baris.Dari segi bahasa, mantra biasanya menggunakan bahasa khusus yang sukar dipahami.

Hampir setiap aktivitas orang Bugis pada masa lampau hingga kini, didahului dengan membaca doa atau baca-baca dengan harapan agar mereka mendapatkan keselamatan dunia dan akhirat. Agar bacabaca yang dibaca mendapat berkah dari Allah SWT, maka si pemakai baca-baca harus memperhatikan beberapa persyaratan. Syarat yang harus senantiasa dijaga adalah tidak boleh diucapkan pada sembarang waktu dan tempat, harus yakin bahwa doa yang diucapkan itu mempunyai daya gaib, serta dipakai dengan maksud untuk membela diri atau menolong orang.

Masyarakat Bugis Bulukumba mengenal dalam komunitasnya istilah Sanro ana', yaitu salah satu istilah yang dijuluki kepada dukun dalam hal yang berhubungan dengan kelahiran anak. Masyarakat kontemporer menggunakan jasa dukun beranak yang dikenal Sanro ana'. Masyarakat Bugis dulunya lebih banyak memilih jasa Sanro ana' untuk membantu persalinan sebab dianggap sakral dan biayanya lebih murah dibandingkan dengan bantuan para medis. Dengan adanya denda yang diperuntukkan kepada masyarakat yang menggunakan jasa sanro anak, membuat masyarakat sangat langka menggunakan jasanya.

Mantra yang digunakan sanro ana' dianggap sangat sakral sehingga tidak sembarang orang yang dijadikan sebagai pewaris dari ilmu tersebut. Bentuk mantra yang digunakan disembunyikan atau dirahasiakan sehingga makna yang dikandungnya tidak dapat diidentifikasi. Dari segi penggunaan, mantra sangat eksklusif, tidak boleh dituturkan sembarangan, karena bacaannya dianggap keramat dan tabu.

Samad (2008), dalam penelitiannya mengungkap tentang "Makna mantra pengusir mahluk astral pada anak bayi di masyarakat Mandar". Penelitian tersebut memaparkan tentang mantra dan arti yang terkandung dalam mantra, serta nilai-nilai yang terkandung dalam doa yang terdapat pada mantra yang dibacakan seorang dukun. 
Cordova Jurnal

ISSN (P) 2302-3155,

(e) 2714-5808

Vol. 9, No. 12019
Jurnal kajian Bahasa dan Budaya terbit 2 kali setahun oleh UPT. Pusat Pengembangan

Bahasa (P2B) UIN Mataram. Tersedia online pada

https://journal.uinmataram.ac.id/index.php/cordova

Mantra biasanya diciptakan dan dilestarikan oleh seseorang, kemudian diwariskan kepada keturunan ataupun orang yang ia anggap akan menggantikan fungsinya sebagai dukun. Adakalanya, dukun sendiri tidak memahami arti sebenarnya mantra yang ia baca, ia hanya memahami kapan mantra tersebut dibaca dan apa tujuannya. Keburaman makna yang terkandung dalam mantra yang digunakannya serta ketidakjelasanfungsi mantra pada tuturan sakral yang dituturkan dukun beranak di setiap rangkaian prosesi dalam tradisi kelahiran anak di masyarakat Bugis.

Tujuan penelitiaan ini adalah untuk menjelaskan makna, bentuk dan struktur serta fungsi mantra dukun beranak dalam tradisi kelahiran tradisional bagi masyarakat Bugis.

\section{METODE PENELITIAN}

\section{Jenis Penelitian}

Jenis penelitian ini adalah penelitian kualitatif, data yang dikumpulkan bukan berupa angka-angka, melainkan data tersebut berasal dari hasil wawancara, catatan di lapangan, dokumen-dokumen, dan sumber lainnya. Tujuan dari penelitian deskriktif-kualitatif ini adalah ingin menggambarkan realita di balik fenomena secara mendalam, rinci dan tuntas di masyarakat. Oleh karena itu, penggunaan pendekatan kualitatif dalam penelitian ini adalah dengan mencocokkan antara realita apa adanya yang terdapat dalam masyarakat dengan teori yang telah ada dengan menggunakkan cara deskriptif.

\section{Sumber Data}

Penentuan informan dengan cara mencari warga yang merupakan sanro ana' di wilayah penelitian. Menanyakan kepada warga setempatsiapa yang berprofesi sebagai sanro ana' dan dipandang memiliki pengetahuan yang relevan dengan objek penelitian. Adapun informan kunci yang dipilih merupakan dukun atau sanro yang mengetahui banyak terkait dengan objek penelitian. Informan ini dinamakan informan utama. 
Cordova Jurnal

ISSN (P) 2302-3155,

(e) 2714-5808

Vol. 9, No. 12019
Jurnal kajian Bahasa dan Budaya terbit 2 kali setahun oleh UPT. Pusat Pengembangan

Bahasa (P2B) UIN Mataram. Tersedia online pada

https://journal.uinmataram.ac.id/index.php/cordova

\section{Metode Pengumpulan Data}

Untuk mencapai teknik pengumpulan data diperlukan tahaptahap atau langkah-langkah untuk memperkuat teknik pengumpulan data. Observasi, pengumpulan data dengan teknik pengamatan atau observasi merupakan cara atau teknik pengumpulan data melalui pengamatan langsung terhadap objek penelitian. Teknik wawancara atau interview, dalam hal ini dilakukan biasanya bersifat terstruktur namun bebas dan mendalam. Teknik Merekam, untuk memudahkan pengumpulan data dalam melakukan penelitian, sangat diperlukan teknik merekam. Teknik mencatat, dalam melakukan penelitian ini juga diperlukan teknik pencatatan. Semua yang dilihat langsung di lokasi penelitian, serta yang didengar dari seluruh yang diucapkan oleh narasumber semuanya sangat perlu dicatat.

\section{Metode Analisis Data}

Analisis data dibagi menjadi beberapa bagian yaitu analisis domain yaitu memberi gambaran umum dari dan menyeluruh dari objek penelitian, analisis taksonomi yaitu penjabaran secara rinci dari analisis domain melalui observasi terfokus, analisis komponensial, yaitu mencari spesifik pada setiap detail struktur internal dan analisis tema kultural yaitu mencari hubungan.Analisis data merupakan bagian sangat penting dalam penelitian ini, karena darianalisis ini diperoleh temuan, baik temuan substantif maupun formal. Selain itu, analisis data kualitatif sangat sulit karena tidak ada pedoman baku, tidak berproses secara linier, dan tidak ada aturan-aturan yang sistematis. Pada hakikatnyaanalisis data adalah sebuah kegiatan untuk mengatur, mengurutkan, mengelompokkan, memberi kode atau tanda, dan mengkategorikannya sehingga diperoleh suatu temuan berdasarkan fokus atau masalah yang ingin dijawab (Spradley, 1997).

\section{HASIL PENELITIAN}


Cordova Jurnal

ISSN (P) 2302-3155,

(e) 2714-5808

Vol. 9, No. 12019
Jurnal kajian Bahasa dan Budaya terbit 2 kali setahun oleh UPT. Pusat Pengembangan

Bahasa (P2B) UIN Mataram. Tersedia online pada

https://journal.uinmataram.ac.id/index.php/cordova

Untuk memenuhi makna kehidupan sosial, sebuah istilah yang secara harfiah bermakna; kehidupan berasal dari kata hidup artinya masih terus bergerak dan bekerja sebagaimana mestinya. Sedangkan, sosial berarti segala sesuatu mengenai masyarakat dan kemasyarakatan. Jadi kehidupan sosial adalah hal yang sangat penting dalam masyarakat, dalam hal keadaan ekonomi, mental, agama masyarakat di Kabupaten Bulukumba. Ketiga hal tersebut merupakan unsur yang cukup penting dalam kebutuhan yang harus dipenuhi dalam kehidupan manusia, masyarakat, maupun negara, dan apabila salah satunya tidak terpenuhi, maka hidupnya tidak akan harmonis.

Penelitian yang dilakukan di Kabupaten Bulukumba dalam mengungkap bentuk, makna dan fungsi mantra yang dituturkan dukun beranak terdapat beberapa mantra yang didapatkan dari informan dari hasil wawancara di lapangan. Mantra terdiri dari 3 bentuk yang dibagi dari tahapan kelahiran anak bagi masyarakat Bugis yakni saat tujuh bulanan, saat pendarahan dan pada proses kelahiran anak. Hasil penelitian ini diambil dari 3 informan yang terdapat di Kabupaten Bulukumba, yang menuturkan mantra dalam 3 tahapan proses kelahiran anak bagi masyarakat Bugis yakni Tujuh Bulanan, Pecah Ketuban dan Proses Kelahiran. Semuanya mantra yang dituturkan sanro ana' dapat dilihat dalam uraian pembahasan.

\section{PEMBAHASAN}

Penelitian ini menemukan adanya transformasi kebudayaan di masyarakat Bugis yang berada di wilayah pedesaan tampaknya antara adat dan kebudayaan islam terdapat unsur-unsur yang sejalan. Hal ini merupakan konsekuensi logis adanya penyatuan antara adat dengan kebudayaan islam. Tanpa adanya kebudayaan manusia tidak akan hidup bersama dan bekerja sama untuk mempertahankan hidup dan eksistensinya. Maka dengan demikian, kebudayaan atau budaya dan masyarakat atau budaya dan masyarakat tidak mungkin dapat dipisahkan karena soal kebudayaan adalah soal manusia. Pembentukan pelaksanaan kebudayaan itu berpangkal pada hidup bersama dan 
Cordova Jurnal

ISSN (P) 2302-3155,

(e) 2714-5808

Vol. 9, No. 12019
Jurnal kajian Bahasa dan Budaya terbit 2 kali setahun oleh UPT. Pusat Pengembangan

Bahasa (P2B) UIN Mataram. Tersedia online pada

https://journal.uinmataram.ac.id/index.php/cordova

berkerjasama sekelompok manusia. Demikian pula halnya agama dengan kebudayaan sulit untuk dipisahkan karena dengan berdasarkan prinsip dan nilai-nilai serta fungsi yang digariskan tanpa kebudayaan manusia tidak akan terbentuk.

Demikian pula halnya yang terjadi pada masyarakat Bugis yang dulunya masih memiliki kepercayaan terhadap benda-benda gaib terlebih lagi jika kita melihat sejarah terbentuknya desa mantra dukun beranak yang turun temurun dijalankan oleh dukun yang berdasarkan teks Bugis, walaupun sekarang sudah di namakan dengan mantra, dimana mantra terbentuk dengan adanya mistik dan bersifat di luar akal sehat dan kelogisan pola pikir manusia sesuai dengan kepercayaan masyarakat itu sendiri. Akan tetapi mantra tersebut masih ada dan dipelihara dengan baik oleh pewarisnya yang diberikan secara turun temurun.

Mantra dukun beranak bagi masyarakat Bugis memiliki bentuk yang mengandung makna dan fungsi yang merupakan suatu bentuk puisi lisan yang tergolong ke dalam puisi tradisional masyarakat Bugis. Dengan demikian, mantra bagi masyarakat Bugis dapat dikategorikan sebagai suatu karya sastra yang menampilkan suatu gambaran kehidupan masyarakat Bugis dan keadaan sosialnya. Mantra dukun beranak ini juga merupakan hasil imajinasi yang turun temurun berfungsi sebagai kepercayaan tersendiri bagi masyarakat setempat dan bagi sanro itu sendiri.

Makna yang dikandung setiap tahapan dalam proses kelahiran anak masyarakat Bugis tidak sama disetiap mantranya. Pada saat masuk umur kandungan tujuh bulan, masyarakat Bugis menggelar upacara atau tradisi yang disebut maccera' wettang yang merupakan ritual selamatan tujuh bulanan. Setiap informan yang merupakan dukun beranak yang berasa di Bulukumba mengandung makna yang simbolis dari mantra yang dimilikinya, pada prosesi ini isi mantra menyiratkan doa dan harapan agar bayi dalam kandungan diberikan kekuatan dan kesehatan sampai tiba saatnya keluar dari rahim ibunya dan lahir ke dunia. Dapat disimpulkan bahwa mantra yang diungkapkan oleh dukun 
Cordova Jurnal

ISSN (P) 2302-3155,

(e) 2714-5808

Vol. 9, No. 12019
Jurnal kajian Bahasa dan Budaya terbit 2 kali setahun oleh UPT. Pusat Pengembangan

Bahasa (P2B) UIN Mataram. Tersedia online pada

https://journal.uinmataram.ac.id/index.php/cordova

beranak pada tradisi tujuh bulanan merupakan bahasa yang mengandung makna kekuatan.

Berbeda makna mantra yang terkandung pada saat ibu yang mengandung akan melahirkan bayinya, yang biasa dilakukan pada saat ibu sudah merasa kesakitan. dukun beranak meniupkan doa agar ibu yang akan melahirkan diberi kemudahan sat proses kelahiran anak, isi mantranya menyiratkan makna yang menyandarkan harapan dan permintaan agar dimudahkan saat bayi dalam kandungan akan keluar. Dari kesemua informan yakni dukun beranak yang mengucapkan mantra yang dimikinya, maka dapat dimaknai sebagau ungkapan doa, harapan dan permintaan untuk diberi kemudahan dalam proses kelahiran. Sehingga makna mantra yang diungkapkan sanro ana' dalam proses kelahiran dalam tahap kesakitan merupakan gaya bahasa yang menjadi tanda bermakna kemudahan.

Pada prosesi kelahiran saat keluarnya bayi dari kandungan ibu, sanro ana' meniupkan atau membacakan mantranya yang bertujuan agar bayi yang berada dalam kandungan dan ibu yang melahirkan diberi kekuatan dan bermohon diberikan keselamatan. Setiap mantra dari masing-masing sanro ana' menyiratkan makna doa yang menjadi permintaan saat perjuangan hidup mati seorang ibu dalam melahirkan anaknya senantiasa diberikan keselamatan. Gaya bahasa yang digunakan dalam mantra pada proses kelahiran mengandung makna keselamatan, sehingga dapat disimpulkan bahwa pada tahapan ini sanro ana' yang membacakan mantranya mengandung makna dari tanda yang merupakan lambing bunyi dari bahasa yang digunakannya bermakna keselamatan.

Mantra dukun beranak bagi masyarakat Bugis memiliki bentuk yang mengandung makna dan fungsi yang merupakan suatu bentuk puisi lisan yang tergolong ke dalam puisi tradisional masyarakat Bugis. Dengan demikian, mantra bagi masyarakat Bugis dapat dikategorikan sebagai suatu karya sastra yang menampilkan suatu gambaran kehidupan Masyarakat Bugis dan keadaan sosialnya. 
Cordova Jurnal

ISSN (P) 2302-3155,

(e) 2714-5808

Vol. 9, No. 12019
Jurnal kajian Bahasa dan Budaya terbit 2 kali setahun oleh UPT. Pusat Pengembangan

Bahasa (P2B) UIN Mataram. Tersedia online pada

https://journal.uinmataram.ac.id/index.php/cordova

Mantra dukun beranak ini juga merupakan hasil imajinasi yang turun temurun berfungsi sebagai kepercayaan tersendiri bagi masyarakat setempat dan bagi sanro itu sendiri. Untuk mengetahui fungsi mantra yang terdapat dalam kata-katanya maka diperlukan pengkajian yang diteliti dengan menggunakan suatu pendekatan yang tepat, pendekatan antropolinguistik sangat relevan dalam mengungkapkan makna yang terkandung di balik mantra dukun beranak masyarakat Bugis di Bulukumba.

Mantra dukun beranak dianggap sakti dan bersifat gaib, maka umumnya hanya dimiliki oleh dukun beranak dan orang-orang tertentu untuk menyebarkannya kepada orang lain, yang bersangkutan haruslah mempunyai pertalian darah dengan pemilik mantra, persebaran tersebut dalam masyarakat Bugis sangat erat kaitannya dalam pewarisan budaya. Namun pada masa sekarang ini, hal tersebut sudah mulai mengalami pergeseran meskipun demikian mantra tetap dimiliki oleh kalangan tertentu.

Mantra terdiri atas beberapa jenis berdasarkan fungsi dan kegunaannya, mantra juga membutuhkan pemilihan kata-kata yang tidak bisa melepaskan diri dari unsur bahasa yang mempunyai pengertian dari satu. Dengan kata lain, karena berhungan denga alam gaib, dan menggunakan pilihan kata pengungkapan yang tepat.

Mengucapkan mantra, serapah, atau doa harus benar-benar dijaga syarat dan pantangannya, seperti waktu yang baik dan waktu dan waktu yang buruk. Setiap kata yang diucapkan haruslah dengan irama (tekanan kata atau kalimat) yang tepat, di samping itu, si pengguna mantra harus tahu benar sejarah dan tujuan setiap perkataan yang diucapkannya. Pikiran pembaca atau pengguna mantra harus bulat (menyatu-padu), memanfaatkan makrifat sebagai sarana untuk menembus alam gaib.

Cara demikian, kekuatan gaib akan muncul dengan kesan sakti di masyarakat, yakni tenaga yang dapat menguasai roh-roh halus atau mahluk tertentu. Bila syarat tidak dipenuhi atau larangan tidak dihindari, kegiatan itu malah dapat menyimpulkan bahwa kata-kata 
Cordova Jurnal

ISSN (P) 2302-3155,

(e) 2714-5808

Vol. 9, No. 12019
Jurnal kajian Bahasa dan Budaya terbit 2 kali setahun oleh UPT. Pusat Pengembangan

Bahasa (P2B) UIN Mataram. Tersedia online pada

https://journal.uinmataram.ac.id/index.php/cordova

dalam mantra yang mengandung kekuatan sakti bukan hanya dapat memesona atau menundukkan manusia biasa, melainkan juga dapat mempengaruhi binatang serta makhluk halus lainnya. Makhluk halus dan alam beserta isinya dapat dimanfaatkan, dipengaruhi, bahkan ditundukkan oleh mantra.

Baca-baca sebagai doa yang dipanjatkan untuk kelancaran proses persalinan anak yang dianggap sakral agar acara tersebut terhindar dari segala sesuatu yang tidak diinginkan yang akan membahayakan Ibu maupun anak, maka keluarga yang akan melahirkan tersebut selalu berinisiatif untuk meminta bantuan atau pertolongan kepada ahlinya yaitu dukun tersebut. Selanjutnya, biasa pula di fungsikan sebagai syarat utama yang dimiliki oleh dukun pada ritual prosesi persalinan yang sedang berlangsung. Semua fungsi yang disebutkan, pada intinya adalah sebagai doa yang sangat memiliki fungsi yang strategis dalam mencapai fungsi-fungsi bagi dukun beranakuntuk membantu proses persalinan anak secara tradisional bagi masyarak Bugis.

Masyarakat Bugis sebagai penganut agama Islam yang taat sangat percaya akan adanya Tuhan yang menciptakan alam semesta. Mantra dukun beranakdi dalamnya terdapat uacapan-ucapan dan keyakinan yang mendalam pada ajaran islam, seperti bacaan dan beberapa surah atau ayat-ayat Al Qur'an tertentu yang diyakini mampu mendatangkan kebaikan atau menghindarkan si pemilik acara dari hal-hal yang membahayakan termasuk yang dapat menghambat persalinan maupun kematian dalam proses persalinan.Integrasi yang merupakan hubungan antara manusia dengan tuhan dengan menggunakan mediasi melalui mantra yang menjadi sarana untuk bermohon dan bermunajab guna meminta kemudahan dan keselamatan jalannya prosesi persalinan.

Bentuk mantra sanro ana' adalah puisi lama atau puisi tradisional yang terdiri dari beberapa baris, namun tidak memiliki rima yang beraturan. Bentuk mantra yang berupa puisi lama yang terdiri dari pembuka, isi dan penutup. Bentuk mantra yang diungkapkan oleh sanro ana' yang menggambarkan singkronisme antara tradisi Islam dengan tradisi lokal masyarakat setempat. 
Cordova Jurnal

ISSN (P) 2302-3155,

(e) 2714-5808

Vol. 9, No. 12019
Jurnal kajian Bahasa dan Budaya terbit 2 kali setahun oleh UPT. Pusat Pengembangan

Bahasa (P2B) UIN Mataram. Tersedia online pada

https://journal.uinmataram.ac.id/index.php/cordova

Kaitannya dengan sanro ana', yang kemampuan baca-baca yang memiliki daya magis, air yaitu darah yang berperan penting dalam diri manusia. Dimana air adalah unsur utama yang dapat berpengaruh penting dalam prosesi tersebut, angin yang dijadikan petunjuk arah memiliki mata. Unsur yang berberan penting dianggap sebagai bentuk penghormatan batin permintaan izin beraktivitas. Mantra yang terkait dengan keempat unsur yang terdapat dalam tubuh secara khusus diucapkan dalam bahasa Bugis ketika prosesi melahirkan berlangsung. Maksud dari mantra ini selain penghormatan dan permintaan izin pada unsur tersebut. Juga agar melangcarkan prosesi persalinan yang sakral dan menegangkan bahkan menakutkan, yang menjadi kekhwatiran dan momok tersendiri bagi keluarga.

Hal tersebut dapat dibuktikan dengan melihat pembuka dan penutup mantra yang merupakan tradisi Islam dengan mengawali sesuatu dengan menyebut nama Allah Tuhan pencipta alam dan menutup mantra dengan mengharapkan berkah dari Allah SWT. Sedangkan pada bagian isi, sanro ana' menyuguhkan kata-kata yang menjadi gaya bahasa masyarakat Bugis yakni bahasa metafora atau perumpamaan dalam mengungkapkan sesuatu. Gaya bahasa yang digunakan tidak mengungkapkan secara langsung sebab dianggap tabuh dan dipamalikan.

\section{SIMPULAN DAN SARAN}

Baca-baca Sanro ana' merupakan mantra atau puisi tradisional yang terdiri dari beberapa baris, namun tidak memiliki rima yang beraturan. Bentuk yang berupa puisi lama yang terdiri dari pembuka, isi dan penutup. Isi mantra tidak dapat dimaknai secara langsung dari setiap kata yang terdapat dalam mantra dukun beranak, sebab katakatanya bermakna metafora atau ungkapan perumpamaan. Bahasa yang tersirat dalam mantra masyarakat Bugis sangat dipamalikan dan sifatnya lumrah apabila dalam isi mantranya menyebutkan objek secara langsung, namun dengan menggunakan bahasa metafora atau perumpamaan. Mantra terdiri atas beberapa jenis berdasarkan fungsi 
Cordova Jurnal

ISSN (P) 2302-3155,

(e) 2714-5808

Vol. 9, No. 12019
Jurnal kajian Bahasa dan Budaya terbit 2 kali setahun oleh UPT. Pusat Pengembangan Bahasa (P2B) UIN Mataram. Tersedia online pada

https://journal.uinmataram.ac.id/index.php/cordova

dan kegunaannya, mantra juga membutuhkan pemilihan kata-kata yang tidak bisa melepaskan diri dari unsur bahasa yang mempunyai pengertian dari satu. Mantra berfungsi sebagai alat utama bagi dukun beranak, pengintegrasian diri dengan Tuhan penciptanya alam semesta, permintaan izin kepada unsur yang terdapat dalam diri manusia, penolak bala' dan doa pengharapan. Perlunya pengetahuan dan praktek bagi generasi pelanjut tentang tradisi kelahiran secara tradisional, agar dapat melestarikan budaya sendiri sebagai warisan dari leluhur secara turun temurun agar budaya dan konsepnya tidak punah. Untuk penelitian selanjutnya, penulis sarankan mengkaji tentang tinjauan secara agama dan persfektif lain tentang mantra sanro ana' melihat posisi tradisi kelahiran tradisonal masyarakat Bugis di era sekarang. 


\section{Daftar Pustaka}

Duranti. 1997. Linguistik Anthropology. Cambridge: Cambridge University Press.

Fole. 1997. Anthropological linguistics: An Introduction. Oxford: Blackwell Published.

Halliday. 1978. Language and Social Semiotic: The Social Interpretation of Language and Meaning. London: Edward Arnold.

Halliday dan Ruqaiya. 1992. Bahasa, Konteks, dan Teks: Aspek Bahasa dalam

Pandangan Semiotik Sosial (terjemahan Asruddin Borori Tau).

Yogyakarta: Gajah Mada University Press.

Hodge, Robert dan Kress. 1988. Social Semiotics. Oxford: Polity Press.

Mattulada. 1997. Kebudayaan, keemanusiaan, dan Lingkungan Hidup.

Makassar.Hasanuddin University Press.

Mattulada.1995. Latoa, Hasanuddin University Press, Makassar.

Moleong. 1995. Metode Penelitian Kualitatif. Bandung: PT.Remaja Rosdakarya.

Kridalaksana. 1982. Kamus Linguistik. Jakarta: PT Gramedia.

Palmer. 1996. Toward A Theory of Cultural Linguistics. USA: The University of Texas Press.

Samad. 2008. Makna mantra pengusir mahluk astral pada anak bayi di masyarakat Mandar. Tesis pada pascasarjana Unhas, Makassar.

Santoso. 2003. Semiotika Sosial: Pandangan Terhadap Bahasa. Surabaya: Pustaka Eurika dan JP Press.

Sibarani. 2008. Antropolinguistik: Antropologi Lingusitik, Linguistik Antropologi. Medan: Poda.

Spradley. (1997). Metode Etnografi. Yogyakarta: PT. tiara Wacana. 